UDC 57.022

\title{
TOXICITY OF UNFERMENTED WASTE RESIDUE OBTAINED IN MICROBIAL DESTRUCTION OF ORGANIC WASTE
}

\author{
O. Bielikova, N. Matvieieva, O. Tashyrev
}

Інститут мікробіології і вірусології ім. Д.К. Заболотного НАН України

\begin{abstract}
Проведено оцінку токсичності для рослин незбродженого залишку, отриманого після мікробної ферментації в горизонтальному ферментері змішаних харчових відходів. Було використано три типи субстрату: грунт (позитивний контроль), пісок (негативний контроль) та експериментальний субстрат, що складався з незбродженого залишку $i$ піску в об'ємному співвідношенні 6:1 (8 г залишку на 1 кг піску). Picm рослин Raphanus sativus i Lathyrus latifolius оцінювали за енергією проростання насіння. Встановлено, що змішаний субстрат є токсичним для рослин, оскільки насіння не проростало. Енергія проростання насіння $R$. sativus ma L. latifolius у грунті становить 90 i 50\%, у піску - 50 і $20 \%$ відповідно. Наявність незбродженого залишку в експериментальному субстраті спричинило повне пригнічення росту рослин.
\end{abstract}

Ключові слова: харчові відходи, проростання насіння, токсичність, мікроорганізми.

Global pollution of the environment as a result of urbanization and the rapid development of industry in the 20 th century became one of the factor which threats human life and health. Food wastes products, processing industry wastes obtained in technological juices, chips and other production are environmentally dangerous garbage. It is dangerous for people and nature and require utilization or wastes burial. Fermentation of using microorganisms is one of the ways for utilization of food wastes. It is known that microbial destruction of organic wastes could be accompanied by synthesis of molecular hydrogen. This is the base for the development of new technologies for fuel production from environmentally hazardous wastes [1-3].

Fatty acids, mercaptans, hydrogen sulfide generated in dumps during slow uncontrolled fermentation of wastes are toxic compounds. In the same time mixed food waste (MFW) is a promising substrate for microbial synthesis of molecular hydrogen. It consists of components belonging to the major classes of organic compounds (carbohydrates, proteins, etc.). These natural components can be destructed by microorganisms.

The lack of effective technologies for MFW utilization is the main reason for the accumulation of great amounts of organic wastes. The use of microorganisms for the fermentation of organic compounds associated with molecular hydrogen synthesis can simultaneously solve the problem of food wastes accumulation and reduces the cost of this biotechnology application [4,5].

However, unfermented solid waste residues remain even after using of the effective microbial degradation process. These lignincellulose residues obtained in biohydrogen and methane producing technologies are not available for the bacteria. It must be disposed or should be used to produce organic fertilizers. For example, worms' composting technology can be used for biohumus production from the biodegradable wastes [6-8].

Untreated wastes contain microorganisms and their metabolic products, including compounds inhibited plant growth. This inhibitory effect is manifested in reducing of seeds germination, slowness of plant growth and root formation. Therefore, it is important to estimate the toxicity of unfermented plant residues produced in the process of microbial destruction of MFW.

In this study we evaluated the toxicity of dry unfermented residues obtained after the fermentation of mixed food wastes in a horizontal bioreactor.

(C) O. Bielikova, N. Matvieieva, O. Tashyrev, 2017 


\section{MATERIALS AND RESEARCH METHODS}

The dry residues were obtained by fermentation of MFW in the horizontal fermenter. In this experiment for evaluation the dry unfermented residues toxicity for the plants we used such types of substrates:

- soil (universal substrate for vegetables and flowers, production «Agrosvit») as a «positive control» substrate;

- sand as a «negative control» substrate;.

- «experimental» substrate consisted of sand and MFWR in volume ratio 6/1 (8 g MFWR per $1 \mathrm{~kg}$ of sand).

The $\mathrm{pH}$ of the soil was determined by bromthymolblau indicator (BTB 0.01\%) using standard BTB $\mathrm{pH}$ scale.

Seeds of Raphanus satious and Lathyrus latifolius were cultivated in soil, sand and experimental substrates for nine days at the temperature of $+20^{\circ} \mathrm{C}$. Experiments were performed in triplicate. We characterized plant growth by the energy of seed germination.

Microbiological soil composition was evaluated before sowing seeds and in 10 days after germination by the number of colony forming units (CFU) of chemoorganotrophic and nitrogen-fixing microorganisms. For this purpose, tenfold dilution was prepared. The dilutions in volume $0.1 \mathrm{ml}$ were plated on $\mathrm{Nu}-$ trient agar media in Petri dishes. Meat-peptone solidified HiMedia medium and Ashby medium were used to count chemoorganotrophic and nitrogen-fixing microorganisms. The number of colonies was determined on the third day of growth at $+28^{\circ} \mathrm{C}$.

\section{RESULTS AND DISCUSSION}

It is known that BTB is an indicator which colour depends on the $\mathrm{pH}$ in the range between 5.8 and 8.0. This allowed us to determine the $\mathrm{pH}$ of the used substrates quickly and reliably. Some differences were shown by $\mathrm{pH}$ analysis of three studied substrates. The $\mathrm{pH}$ of soil was more acidic than the sand one and the experimental substrate $-6.6-6.8$, $7.4-7.8$ and $7.4-7.6$ respectively. Thus, the addition of MFWR to sand did not affect significantly on the $\mathrm{pH}$ value.

The mixed substrate that contained unfermented residues was found to be toxic for the plants. Seedlings were not formed even after 10 days of such cultivation conditions, while in control substrates the first shoots were observed in 3 days after seeds sowing. Germination energy of seeds of Raphanus sativus and Lathyrus latifolius planting in the soil was $90 \%$ and $50 \%$, in the sand $-50 \%$ and $20 \%$ respectively. Thus, addition of unfermented residues in experimental substrate resulted in complete inhibition of growth.

There are two possible reasons of the inhibition of plants growth in the mixed substrate. Firstly, it is the presence of toxic compounds which can inhibit the growth of plants. Secondly, it is the presence of large amounts of microorganisms that negatively affect plants growth and lead to seeds death.

The CFU of heterotrophic and nitrogenfixing microorganisms were analyzed in studied substrates. The amount of nitrogen-fixing and heterotrophic microorganisms in the soil and experimental substrate was higher than in the sand. Thus, the CFU of heterotrophic microorganisms was $1.04 \times 10^{8}, 1.64 \times 10^{8}$ and $7.2 \times 10^{6}$, respectively, in soil, experimental substrate and sand. The greatest number of nitrogen-fixing microorganisms was found in a mixed substrate, $\mathrm{CFU}=2.8 \times 10^{7}$, and the smallest - in the sandy substrate $-9.2 \times 10^{6}$. The number of heterotrophic microorganisms in the experimental substrate was in 1.57 times higher than in the soil, and in 14 times more than in the sand without the addition of wastes. The amount of nitrogenfixing microorganisms in the waste mixture with sand was 1.5 times higher than in the soil substrate, and 100 times higher than in the sand. These data indicated a significant increase of heterotrophic and nitrogen-fixing microorganism content in the experimental substrate.

Experimental substrate was characterized not only by higher CFU value, but also by larger variety of heterotrophic microorganisms compared to other substrates. In particular, four morphotypes of heterotrophic microorganisms were identified both in soil and sand substrates and six morphotypes of microorganisms were identified in the mixed substrate. At the same time, the variety of mic- 
roorganisms in this substrate was less than in soil and sand (only two morphotypes), while the number of nitrogen-fixing microorganisms was greater compared to other substrates. The obtained data demonstrated a great amount of CFU of heterotrophic and nitrogen-fixing microorganisms in mixed substrate. It may be one of the causes of complete inhibition of germination of plant seeds.

\section{CONCLUSIONS}

Thus, dry residues obtained after fermentation of mixed food wastes, had a toxic effect on the plants growth, which was resulted in complete inhibition of germination. This effect did not depend on the plant species. The number of germinated seeds in the soil was 1.8-2.5 times higher than in the sand. It was natural because the nutritional value of the soil (composition, the amount of organic and inorganic compounds) was higher than the nutritional value of sand. The greater number of heterotrophic microorganisms in the experimental substrate (1.57 times) in comparison with microorganism's number in soil may be the reason of seeds germination inhibition.

\section{REFERENCES}

1. Tashyreva A. The novel comprehensive approach for non-food agricultural and landfill biomass microbial fermentation and biogas production / A. Tashyreva, O. Tashyrev, I. Prytula // Biotechnology and Plant Breeding Perspectives; Eds. R.K. Behl and Edward Arseniuk. - Agrobios (International) Publishers. - 2014. - P. 347-356.

2. Hydrogen Production by the Thermophilic Bacterium Thermotoga neapolitana / N. Pradhan, L. Dipasquale, Giuliana d'Ippolito et al. // Int. J. Mol. Sci. - 2015. - Vol. 16. - P. 12578-12600.

3. Biohydrogen production from biomass and industrial wastes by dark fermentation / M.-L. Chong, V. Sabaratnam, Y. Shirai, M.A. Hassan // Int. J. of Hydrogen Energy. - 2009. - Vol. 34. - P. 3277-3287.

4. Das $D$. Advances in biological hydrogen production processes / D. Das, T. N. Veziroglu // Int. J. Hydrog. Energy. - 2008. - Vol. 33. - P. 6046-6057.
5. Das D. Hydrogen production by biological processes: a survey of literature / D. Das, T. N. Veziroglu // Int. J. Hydrog. Energy. - 2001. - Vol. 26. P. 13-28.

6. Suteu D. Biohumus production by worms' composting of some food wastes / D. Suteu, C. Zaharia, M. Badeanu //Scientific Study \& Res. Chem. \& Chem. Eng., Biotechnol., Food Industry. - 2012. - Vol. 13, No. 2. - P. 169-176.

7. Suteu D. Valorisation of biodegradable waste using worm `s cropping / D. Suteu, M. Badeanu, C. Zaharia // Lucrari Stiintifice. - 2009. - Vol. 52. P. 1173-1178. - (Series: Horticultura).

8. Manukovsky N.S. Two-stage biohumus production from inedible potato biomass / N.S. Manukovsky, V.S. Kovalev, I.V. Gribovskaya // Bioresour Technol. - 2001. - Vol. 78, No. 3. - P. 273-275.

\section{REFERENCES}

1. Tashyreva A., Tashyrev O., Prytula I.; Eds., R.K. Behl and Edward Arseniuk (2014). The novel comprehensive approach for non-food agricultural and landfill biomass microbial fermentation and biogas production. Biotechnology and Plant Breeding Perspectives, Agrobios (International) Publ., ISBN: 978-93-81191-01-9, pp. 347-356 (in English).

2. Pradhan N., Dipasquale L., Giuliana d'Ippolito et al. (2015). Hydrogen Production by the Thermophilic Bacterium Thermotoga neapolitana. Int. J. Mol. Sci., Vol. 16, pp. 12578-12600 (in English).

3. Chong M.-L., Sabaratnam V., Shirai Y., Hassan M.A. (2009). Biohydrogen production from biomass and industrial wastes by dark fermentation. Int. J. of Hydrogen Energy, Vol. 34, pp. 3277-3287(in English).

4. Das D., Veziroglu T.N. (2008). Advances in biological hydrogen production processes. Int. J. Hydrog. Energy, Vol. 33, pp. 6046-6057(in English).
5. Das D, Veziroglu T.N. (2001). Hydrogen production by biological processes: a survey of literature. Int. J. Hydrog. Energy, Vol. 26, pp. 13-28 (in English).

6. Suteu D., Zaharia C., Badeanu M. (2012). Biohumus production by worms' composting of some food wastes. Scientific Study \& Res. Chem. \& Chem. Eng., Biotechnol., Food Industry, Vol. 13, No. 2, pp. 169-176 (in English).

7. Suteu D., Badeanu M., Zaharia C. (2009). Valorisation of biodegradable waste using worm`s cropping. Lucrari Stiintifice, series: Horticultura, Vol. 52, pp. 1173-1178 (in English).

8. Manukovsky N.S., Kovalev V.S., Gribovskaya I.V. (2001). Two-stage biohumus production from inedible potato biomass. Bioresour Technol, Vol. 78, No. 3, pp. 273-275 (in English). 